\title{
Distribution of the gilthead seabream, Sparus aurata Linnaeus, 1758 (Perciformes) in waters of Ukraine
}

\author{
Leonid G. Manilo1 \\ Kostiantyn A. Redinov ${ }^{2}$ \\ ${ }^{1}$ National Museum of Natural History, NAS of Ukraine (Kyiv, Ukraine) \\ 2 Kinburn Spit Regional Landscape Park (Ochakiv, Ukraine)
}

Distribution of the gilthead seabream, Sparus aurata Linnaeus, 1758 (Perciformes) in waters of Ukraine. - L. G. Manilo, K. A. Redinov. - The gilthead seabream (Sparus aurata Linnaeus, 1758) is distributed in the East Atlantics from the British Isles to Senegal, the Canary Islands, and Cape Verde being also common in the Mediterranean Basin. In the Black Sea, the species was first recorded in 1933 along the shore near Romania. Currently, the species occurs here in coastal waters of Ukraine, Turkey, Bulgaria, Romania, and Georgia. In waters of Ukraine, the gilthead seabream was first recorded in 1999 at the mouth of Balaklava Bay. In the northwest part of the Black Sea, the species was first recorded in 2004 in the Dnipro-Bug Estuary. The species was recorded the most frequently in coastal waters of the southern part of the Crimean Peninsula, from Sevastopol to Cape Aya, and in Yahorlyk and Tendra Bays in the northern part of the Black Sea. According to the fish collection of the National Museum of Natural History, NAS of Ukraine and literature sources, the gilthead seabream also occurs in the seaside along the Danube Delta (mouth Skhidne), in the southeast part of the Sea of Azov, and in the Dnipro-Bug Estuary. The specimen caught on 8.10.2008 near mouth Skhidne and a female caught in the Dnipro-Bug Estuary on 23.11.2018 are deposited in the fish collection of NMNH NAS of Ukraine (No. 8741 and No. 10435, respectively). A brief morphological description of the latter specimen is presented, including 6 meristic and 20 plastic characters, colouration, and physiological state. The gilthead seabream can be considered as partly acclimatized species of the Black Sea, although data on its spawning here are absent. The increase in the number of the species in the AzovBlack Sea Basin might indicate that the gilthead seabream entered the Black Sea independently through the Bosporus (process of "mediterranezation"), although simultaneous accidental release of specimens into the sea when cultivated as an object of mariculture cannot be excluded. In particular, the gilthead seabream is cultivated in coastal waters of Turkey.

Key words: gilthead seabream, Sparus aurata, northern Black Sea, distribution, morphology.

\section{Introduction}

The gilthead seabream, Sparus aurata Linnaeus, 1758 belongs to the family of seabreams or Porgies (Sparidae) and occurs in the Eastern Atlantic from the British Isles to Senegal, the Canary Islands, and Cape Verde, as well as in the Mediterranean Sea. The species is also distributed in the Black Sea in coastal waters of Turkey, Bulgaria, Romania, Ukraine, and Georgia.

In many countries of the Mediterranean Basin (Portugal, Spain, Tunisia, France, Italy, Greece, Cyprus, and Turkey) and of the Persian Gulf, S. aurata is widely cultivated in lagoons, tank, and cage aquaculture. The annual aquaculture production and global wild capture of the species in 2014 reached 158400000 t and 9500 t, respectively (Boltachev, Karpova, 2017). In 2007, S. aurata was recorded in the Gulf of California (Mexico), where its unexpected appearance was explained by the species' cultivation in mariculture (Balart et al., 2009).

The gilthead seabream is a benthic-pelagic, euryhaline, and eurytherm species inhabiting rocky, sandy, and silty bottoms to a depth of $500 \mathrm{~m}$, although it is more common to $150 \mathrm{~m}$ (Abecasis et al., 2008). In the past decade, an increase in the species richness of the family Sparidae (6-7 species) has been observed in coastal waters of Georgia and the Crimea, Ukraine. Moreover, in Georgia it became the second most widely distributed species of Sparidae after the annular seabream, Diplodus annularis (Guchmanidze, Boltachev, 2017).

Correspondence to: L. G. Manilo; National Museum of Natural History, National Academy of Sciences of Ukraine; Bohdan Khmelnytsky St. 15, Kyiv, 01030 Ukraine; e-mail: leonid.manilo@gmail.com; orcid: 00000002-7143-9470 
The aim of the present study is to analyse a new record of the gilthead seabream from the northwest part of the Black Sea and generalise data on its records in waters of Ukraine.

\section{Material and Methods}

A specimen of Sparus aurata deposited in the fish collection of the National Museum of Natural History, NAS of Ukraine (Kyiv, Ukraine). Label data: No. 10345, Kinburn Spit, Dnipro-Bug Estuary, Black Sea (vicinities of Pokrovske, Ochakiv Raion, Mykolaiv Oblast, Ukraine), collected on 23 October 2018 by K. O. Redinov.

Measurements of morphometric characters were taken by a digital calliper with an accuracy of $0.1 \mathrm{~mm}$ following the method of Pravdin (1966) proposed for character measurements in fishes of the family Percidae.

\section{Results and Discussion}

Distribution. S. aurata was first recorded in the Black Sea in 1933 near the shores of Romania (Svetovidov, 1964). In waters of Ukraine, the species was first discovered in August 1999 at the mouth of Balaklava Bay, Crimean Peninsula (Boltachev, Yurakhno, 2002). In the following years, the gilthead seabream was regularly spotted and caught by spearfishers in the seashore zone from Sevastopol to Cape Aya (Boltachev, Karpova, 2014).

The first reliable record of S. aurata in the northwest part of the Black Sea is dated to 2004 and it was reported from the vicinities of Vasylivka, in particular near Volyzhin Les, one of the sites of the Black Sea Biosphere Reserve, where the fish was caught $1 \mathrm{~km}$ far from the shore (Tkachenko, 2005). After the first record, from 1-2 to 10 specimens of the gilthead seabream were discovered annually in Tendra and Yahorlyk Bays and considered there as rare and sporadic species (Tkachenko, 2012).

On 23 October 2018, in the western vicinities of Pokrovske, Ochakiv Raion, Mykolaiv Oblast, i.e. in the northeast part of Kinburn Spit from the side of the Dnipro-Bug Estuary, a large specimen of the gilthead seabream was caught by spin fishing from a boat 100-150 $\mathrm{m}$ far from the shore. The fish was frozen and passed to the National Museum of Natural History, NAS of Ukraine (Kyiv) by K. O. Redinov. The specimen was fixed in $4 \%$ formaldehyde solution and deposited into the fish collection (Fig. 1).

However, this is not the first record of the species in this area. Based on unconfirmed reports (the specimen was not preserved), the species was noted in the Chronicle of Nature of the Black Sea Biosphere Reserve based on a record from November 1989 in the eastern part of Tendra Bay near Smolenyi Island (Tkachenko, 2005).

In addition, there is a specimen of the gilthead seabream preserved in the fish collection of the National Museum of Natural History, NAS of Ukraine (No. 8741) having a standard body length of $350 \mathrm{~mm}$, which was caught on 8 October $2008100 \mathrm{~m}$ far from the shore near the river mouth Skhidne in the Danube Delta. Another record of the species was reported from the southeast part of the Sea of Azov (Milovanov, Dubovik, 2013).

All known record localities of the species in the northern Azov-Black Sea Basin are shown in Fig. 2.

Morphology. Unfortunately, descriptions of morphometric characters of caught specimens are not reported in available sources, except for Boltachev and Yurakhno (2002). Therefore, we consider important to describe the gilthead seabream specimen caught in the Dniepro-Bug Estuary.

Specimen No. 10345: o, TL 490 mm, SL 396 mm.

Meristic characters: D XI+14, $A$ III 11, P I 16, V I 5, ll 81, sp.br. 13.

Plastic (morphometric) characters.

1) \% of standard length: head length 29.1, maximum body length 38.5, caudal peduncle depth 9.3, anterodorsal distance 37.8, antepectoral distance 29.2, anteventral distance 35.1, anteanal distance 65.8, postdorsal distance 16.9, caudal peduncle length 18.0, length of $\mathrm{D}$ base 55.8 , maximum height of $\mathrm{D} 11.7$, length of A base 21.8, height of the 3rd spine 7.0, length of P 32.9, length of V 16.9; 


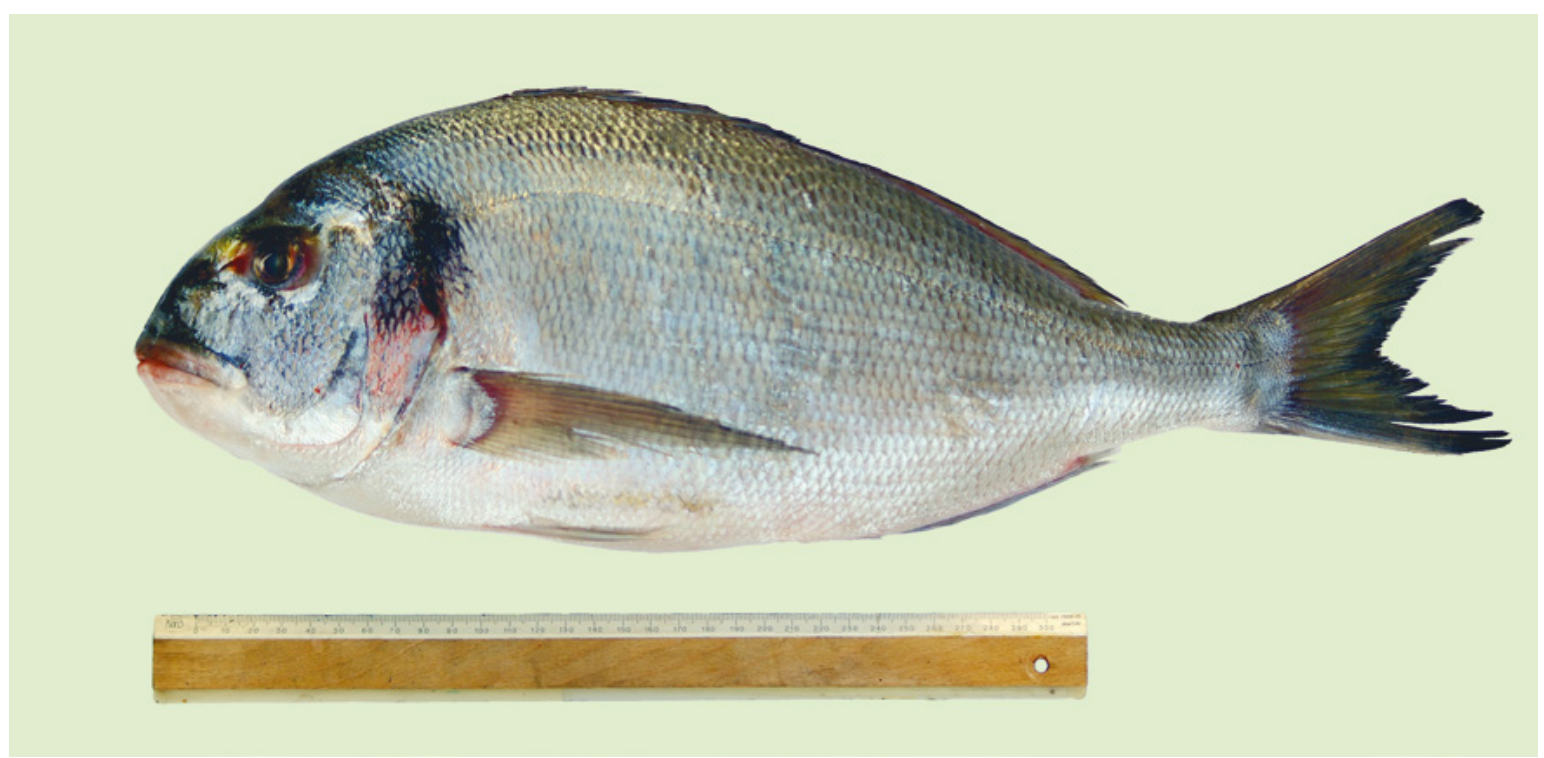

Fig. 1. Gilthead seabream S. aurata from the Dnipro-Bug Estuary. Scale ruler length is $300 \mathrm{~mm}$.

Рис. 1. Золотистый спар S. aurata із Дніпровсько-Бузького лиману. Довжина лінійки для шкали 300 мм.

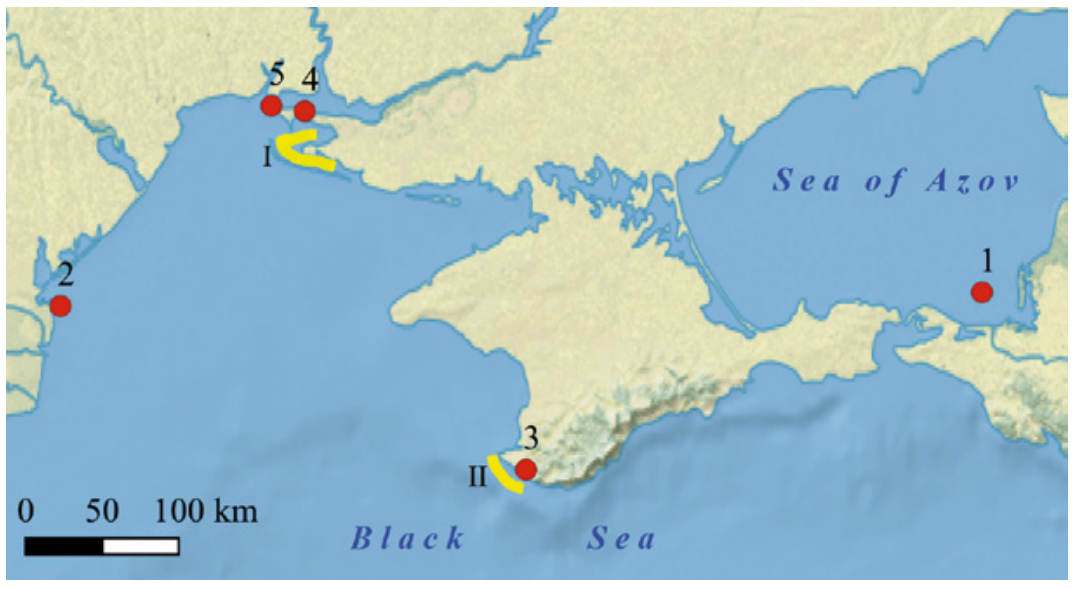

Fig. 2. Records of $S$. aurata in the northern Azov-Black Sea Basin. 1 - Sea of Azov, $2-$ mouth Skhidne, 3 - Balaklava, 4 - Volyzhin Les, 5 - Kinburn Spit; I - Yahorlyk and Tendra Bays, II - Cape KhersonesCape Aya.

Рис. 2. Знахідки S. aurata у північній частині Азово-Чорноморського басейну. 1 - Азовське море, 2 - дельта Дунаю (гирло Східне), 3 - Балаклава, 4 - Волижин ліс, 5 - Кінбурзька коса; I - Ягорлицька та Тендрівська затоки, II мис Херсонес-мис Айя.

2) \% of head length: head depth vertically through the middle of the eye 88.8 , rostrum length 45.3 , horizontal diameter of the eye 17.9, postorbital distance 47.6, interorbital distance 34.8 .

Teeth and colouration. Six conical teeth with rounded tips in the front part of each jaw followed by small rounded teeth. Lateral teeth placed in 3 rows, which corresponds to the description by Svetovidov (1964). Silvery body colouration; white belly. A dark spot at the base of pectoral fins. A large black spot on the upper part of operculum that continues along to the lateral line, from which a red-pink strip runs downward. A bright yellow strip with dark edging between the eyes. A dark strip along the middle part of the dorsal fin. Caudal fin with dark edging.

The gilthead seabream is characterised by protandrous hermaphroditism (Svetovidov, 1964). As a male, it becomes mature in the age of 2 years at a body length up to $30 \mathrm{~cm}$, while it transforms into female in the age of 3 years and at a body length of $33-40 \mathrm{~cm}$. The gonads of the studied female were on the III stage of maturation and its age, determined based on the scales, was 6 years. 


\section{Conclusions}

Based on the obtained data we can conclude that the first appearance of $S$. aurata in the Black Sea in the early 1930s was the result of expansion (auto-acclimatization) from the Mediterranean Sea through the Bosporus due to the permanent process of "mediterranization" that has lasted for 7 500-8 000 years. However, the appearance and development of many marine farms in Turkey during the past decade that specialise on the gilthead seabream's cultivation as an object of monoculture allows considering episodes of random escape of juveniles from culture.

Considering all previous and the last record of $S$. aurata we suggest that the species spreads actively in the Black Sea, including coastal waters of Ukraine, adapting to the new abiotic and biotic conditions. However, we disagree with the view of A. R. Boltachev and E. P. Karpova (2014) that the gilthead seabream has formed a sustainable population near the Crimea since there is no data on its spawning neither here nor in other parts of the Black Sea.

\section{References}

Abecasis, D., L. Bentes, R. Coelho, C. Correia, P. G. Lino, M. Monteiro, S. Goncalves, J. S. Ribeiro, K. Erzini. 2008. Ageing seabreams: A comparative study between scales and otoliths. Fisheries Research, 89: 37-48.

Balart, E. F., J. C. Perez-Urbiola, L. Campos-Davila, M. Monteforte-Sanchez, A. Ortega-Rubio. 2009. On the first record of a potentially harmful fish, Sparus aurata in the Gulf of California. Biological Invasions, 11 (3): 547-550.

Boltachev, A. R., V. M. Yurakhno. 2002. New evidence of ongoing mediterranization of the Black Sea ichthyofauna. Voprosy ikhtiologii, 42 (6): 744-750. (In Russian)

Boltachev, A. R., E. P. Karpova. 2014. Faunistic revision of alien fish species in the Black Sea. Russian Journal of Biological Invasions, 5 (4): 225-241.

Boltachev, A. R., E. P. Karpova. 2017. Marine Fishes of the Crimean Peninsula. 2nd edition: revised and enlarged. Biznes-Inform, Simferopol, 1-376. (In Russian)

Guchmanidze, A., A. Boltachev. 2017. Notification of the first sighting of sand steenbras Lithognathus mormyrus (Linnaeus, 1758) and modern species diversity of the family Sparidae at the Georgian and Crimean Black Sea coasts. Black Sea \& Mediterranean Environment, 23 (1): 48-55.

Milovanov, A. I., V. E. Dubovik. 2013. The first finding of Sparus aurata L., 1758 (Sparidae, Perciformes) in the Sea of Azov. Morskoj Ehkologicheskij Zhurnal, 12 (4): 52. (In Russian)

Pravdin, I. F. 1966. Guide to Studying Fishes. Pishchevaja promyshlennost, Moscow, 1-376. (In Russian)

Svetovidov, A. N. 1964. Fishes of the Black Sea. Nauka, Moscow, Leningrad, 1-550. (In Russian)

Tkachenko, P. V. 2005. A find of the Sparus aurata (Perciformes, Sparidae) in the northwestern part of the Black Sea. Vestnik zoologii, 39 (2): 89-90. (In Russian)

Tkachenko, P. V. 2012. The Fishes of Tendra and Yahorlyk Bays and adjacent waters of the Black Sea. Natural almanac. Biological sciences (Kherson), 18: 181-193. (In Russian) 